\title{
KEWENANGAN BALAI BESAR TAMAN NASIONAL KERINCI SEBLAT DALAM PENEGAKAN HUKUM TERHADAP PERAMBAHAN HUTAN DI TAMAN NASIONAL KERINCI SEBLAT
}

\author{
Ivan Fauzani Raharja \\ Program Khusus Hukum Administrasi Negara Fakultas Hukum Universitas Jambi \\ J. Raya Jambi-Ma. Bulian KM.15 \\ Email : ivanfauzani_fh@unja.ac.id \\ Eko Nuriyatman \\ Program Khusus Hukum Administrasi Negara Fakultas Hukum Universitas Jambi \\ Jl. Raya Jambi-Ma. Bulian KM.15 \\ Email : ekonuriyatman@unja.ac.id \\ Bunga Permatasari \\ Program Khusus Hukum Administrasi Negara Fakultas Hukum Universitas Jambi \\ JI. Raya Jambi-Ma.Bulian KM.15 \\ Email : bungapermatasari@unja.ac.id
}

\begin{abstract}
Law the Republic of Indonesia Number 41 of 1999 concerning Forestry defines Forest is a unit of ecosystem in the form of a stretch of land containing biological natural resources dominated by trees in their natural environment, which cannot be separated from one another, in this research researchers conduct research Large Kerinci Seblat National Park (BBTNKS) and at the location of Kerinci Seblat National Park (TNKS), where this study obtained data that in the TNKS area forest encroachment activities are activities for forest clearing with the aim of owning, controlling and utilizing the results forest without seeing and paying attention to the main functions carried out by a forest area. The forest encroachment activities carried out by the community in the TNKS area for agricultural activities which arise due to the need for agricultural land and only a few people in the TNKS area that has their own agricultural land. In this study discussed two things, namely regarding the authority of regional government supervision in overcoming forest encroachment in the TNKS area and the form of forest encroachment control by BBTNKS in the Kerinci National Park area. The research method used in this study is a non doctrinal (empirical) research method to discuss the incompatibility between dasolen and dasein, and to interview several parties that make it possible to provide information related to ongoing research.
\end{abstract}

Keywords: Authority of BTNKS, Law Enforcement, Forest Encroachment.

\begin{abstract}
Abstrak
Undang-Undang Republik Indonesia Nomor 41 Tahun 1999 Tentang Kehutanan mendefinisikan Hutan adalah suatu kesatuan ekosistem berupa hamparan lahan berisi sumber daya alam hayati yang didominasi pepohonan dalam persekutuan alam lingkungannya, yang satu dengan yang lainnya tidak dapat dipisahkan, dalam penelitin ini peneliti melakukan penelitian pada Balai Besar Taman Nasional Kerinci Seblat (BBTNKS) dan pada lokasi Taman Nasional Kerinci Seblat (TNKS), yang mana penelitian ini mendapat data bahwa dalam kawasan TNKS kegiatan perambahan hutan yang mana kegiatan ini merupakan sebuah kegiatan pembukaan hutan dengan tujuan untuk memiliki, menguasai dan memanfaatkan hasil hutan tanpa melihat dan memperhatikan fungsi pokok yang diemban oleh suatu kawasan hutan. Kegiatan perambahan hutan yang dilakukan oleh masyakat pada kawasan TNKS adalah untuk kegiatan pertanian yang mana timbul dikarenakan adanya kebutuhan lahan pertanian dan hanya sedikit masyarakat yang berada dalam kawasan TNKS yang memiliki lahan pertanian sendiri. Dalam penelitian ini membahas dua hal, yaitu mengenai kewenangan
\end{abstract}


pengawasan pemerintah daerah dalam penanggulangan perambahan hutan di kawasan TNKS dan bentuk penanggulangan perambahan hutan oleh BBTNKS di kawasan TNKS wilayah Kabupaten Kerinci. Metode penelitian yang digunakan dalam penelitian ini adalah metode penelitian non doctrinal (empiris) untuk membahas ketidak serasian antara dasolen dan dasein, serta mewawancarai beberapa pihak yang memungkinkan memberikan informasi tetrkait dengan penelitian yang berlangsung.

Kata Kunci: Kewenangan BTNKS, Penegakan Hukum, Perambahan Hutan.

\section{Pendahuluan}

Undang-Undang Republik Indonesia Nomor 41 tahun 1999 tentang Kehutanan mendefinisikan Hutan adalah suatu kesatuan ekosistem berupa hamparan lahan berisi sumber daya alam hayati yang didominasi pepohonan dalam persekutuan alam lingkungannya, yang satu dengan yang lainnya tidak dapat dipisahkan. Hutan Indonesia merupakan salah satu hutan tropis terluas di dunia sehingga keberadaannya menjadi tumpuan keberlangsungan kehidupan bangsa-bangsa di dunia, khususnya dalam mengurangi dampak perubahan iklim global. Pemanfaatan dan penggunaannya harus dilakukan secara terencana, rasional, optimal dan bertanggung jawab sesuai dengan kemampuan keseimbangan lingkungan hidup guna mendukung pengelolaan hutan dan pembangunan yang berkelanjutan bagi kemakmuran rakyat.

Selama 50 tahun terakhir hutan Indonesia telah berkurang penutupan hutannya sekitar $25-40 \%$ (40-60 juta ha). Kondisi tersebut disebabkan karena terjadinya eksploitasi hutan yang tidak memperhatikan aspek kelestarian hutan, menyebabkan terjadinya kerusakan lingkungan, kepunahan jenis flora dan fauna, konflik sosial, hilangnya pendapatan pemerintah dan kegagalan untuk mempertahankan sumber daya alam untuk generasi mendatang.
Perambahan hutan merupakan suatu kegiatan pembukaan hutan dengan tujuan untuk memiliki, menguasai dan memanfaatkan hasil hutan tanpa melihat dan memperhatikan fungsi pokok yang diemban oleh suatu kawasan hutan. Semua aktifitas yang terjadi di dalam kawasan hutan negara yang berjalan dan terjadi tanpa restu (izin) dari representasi kelembagaan negara adalah illegitimated. Perambah dapat diartikan sebagai individu maupun antitas baik berupa orang perorang, kelompok atau yang lebih formal dalam pengertian sebagai badan hukum. Aktifitas "perambah tidak terbatas pada usaha perkebunan atau pertanian saja tetapi dapat juga dalam bentuk penjarahan hutan dengan membakar kayu-kayu yang sudah di tebang dan ada juga yang mengambil kayu-kayunya ataupun bentuk usaha lain yang menjadikan kawasan sebagai tempat berusaha secara illegal."1

Soemendar berpendapat bahwa pemerintah sebagai badan yang penting dalam rangka pemerintahannya, pemerintah semestinya memperhatikan ketentraman dan ketertiban umum, tuntutan dan harapan serta pendapat rakyat, kebutuhan dan kepentingan masyarakat, pengaruh-pengaruh lingkungan, pengaturan-pengaturan, komunikasi peran serta seluruh lapisan masyarakat dan legitimasi. $^{2}$

1 Totok Dwi Diantoro, Perambahan Kawasan Hutan Pada Konservasi Taman Nasional, Mimbar Hukum, Volume 23, Nomor 3, Oktober 2011, hlm. 551-552.

2 Inu Kencana Syafiie, IImu Pemerintahan, Cet. 2 Bumi Aksara, Jakarta, 2014, hlm. 12. 
Menurut Prajudi Atmosudirdjo 1984, "tugas pemerintah antara lain adalah tata usaha negara pemerintahan, pembangunan, dan pelestarian lingkungan hidup, sedangkan fungsi pemerintah adalah pengaturan, pembinaan masyarakat, kepolisian dan peradilan."3 Menyimak ketentuan yang khusus mengatur tentang perlindungan hutan sebagaimana yang diatur oleh Peraturan Pemerintah Republik Indonesia Nomor 45 tahun 2004 Tentang Perlindungan Hutan merupakan tanggung jawab pemerintah maupun pemerintah daerah sebagai pelaksana tugas negara untuk mengatur, melindungi dan mensejahterakan masyarakatnya. Oleh sebab itu, salah satu tugas berat yang ditanggung oleh pemerintah maupun pemerintah daerah, adalah bagaimana caranya agar masyarakat sejahtera, khususnya masyarakat yang bermukim di sekitar hutan dengan cara tidak merusak hutan. ${ }^{4}$

Undang-Undang Republik Indonesia Nomor 41 Tahun 1999 Tentang Kehutanan dalam Pasal 50 dan ketentuan pidana diatur dalam Pasal 78. Sumber daya merupakan salah satu ciptaan tuhan yang maha kuasa yang memiliki peranan yang sangat penting dalam menjaga keseimbangan alam di jagad raya ini. Sebab di dalam hutan telah diciptakan segala makhluk hidup baik besar, kecil maupun yang tidak dapat dilihat dengan mata. Hutan di Indonesia mempunyai peranan penting baik ditinjau dari aspek ekonomi, sosial, budaya maupun ekologi. Namun dengan demikian sejalan dengan pertumbuhan penduduk dan pertumbuhan nasional, tekanan terhadap sumber daya hutan semakin meningkat.

Kegiatan perambahan hutan yang terjadi di TNKS telah mampu mengikis kelestarian dari TNKS dan hutan lindung lainnya yang berada di daerah ini. Taman nasional merupakan "kawasan pelestarian alam yang mempunyai ekosistem asli yang dikelola dengan sistem zonasi untuk keperluan ilmu pengetahuan, pendidikan, penunjang budidaya tumbuhan dan/atau satwa, pariwisata dan rekreasi." Pada tataran dan tahap lainnya pengetahuan masyarakat tentang batas taman nasional memegang peran penting dalam efektifitas pengelolaan taman nasional. Jika masyarakat mengetahui ketentuan-ketentuan hukum tentang taman nasional, seperti tidak diperbolehkan menggarap atau mengambil sumberdaya dalam kawasan taman nasional, maka pengelolaan kawasan akan berjalan efektif. Namun jika sebaliknya apabila masyarakat tidak mengetahui batas-batas taman nasional maka pengetahuan dan pelaksanaan hukum tersebut menjadi kurang efektif. Sebagian besar masyarakat tidak mengetahui atau melihat adanya batas kawasan TNKS. Perambahan kawasan TNKS untuk kegiatan pertanian disebabkan karena adanya kebutuhan lahan pertanian, karena hanya sedikit masyarakat yang memiliki lahan pertanian. Jika batas kawasan TNKS tidak jelas atau tidak diketahui oleh masyarakat setempat maka peluang terjadinya perambahan semakin besar, "persoalan ketidak jelasan batas kawasan akan menyebabkan persoalan yang serius bagi administrasi taman nasional. ${ }^{6}$

Masyarakat di sekitar hutan atau kawasan perlindungan ini pada umumnya berpendidikan rendah, tidak banyak berhubungan dengan dunia luar dan dengan sistem pertanian yang masih sederhana. Ketidak tahuan masyarakat mengenai - 
batas kawasan TNKS dipengaruhi oleh tingkat pendidikan masyarakat tersebut. Rendahnya pengetahuan masyarakat mengenai fungsi dan manfaat kawasan perlidungan juga dikarenakan ketidak pahaman mereka akan kategorisasi suatu kawasan yang dijadikan kawasan perlindungan.

Persoalan penting dalam kawasan perlindungan adalah bukan sekedar memberikan informasi tentang apa kawasan konservasi tetapi juga bagaimana masyarakat umumnya dan masyarakat di sekitar kawasan khususnya memahami fungsi kawasan dan bagaimana membangun kesadaran untuk memeliharanya selain memanfaatkan sebijak mungkin sesuai dengan fungsi kawasan. Masyarakat saat ini sudah menganggap kawasan perlindungan sebagai kawasan yang berpotensi besar dalam menghasilkan uang. ${ }^{7}$

Berdasarkan informasi awal yang penulis peroleh dari salah satu pegawai Balai Besar Taman Nasional Kerinci Sebelat di Kabupaten Kerinci bahwa potensi perambahan hutan di kawasan TNKS wilayah Provinsi Jambi pada tahun 2013 terjadi perambahan hutan sebanyak 28.255 ha, pada tahun 2014 sebanyak 28.255 ha, pada tahun 2015 sebanyak 28.255 ha, pada tahun 2016 sebanyak 28.255 ha dan pada tahun 2017 sebanyak 28.255 ha. Sedangkan untuk wilayah Kabupaten Kerinci potensi perambahan hutan yang terjadi pada tahun 2013 adalah sebanyak 24.700 ha dan pada tahun 2014 sebanyak 6.720 ha, untuk tahun-tahun setelahnya belum terdata di kantor Balai Besar Taman Nasionak Kerinci Seblat (BBTNKS).

Berdasarkan data potensi perambahan hutan di kawasan TNKS di atas menimbulkan keprihatinan bagi peneliti karena perambahan hutan selalu terjadi dari tahun ke tahun dan juga tidak lengkapnya data perambahan hutan untuk wilayah Kabupaten Kerinci menimbulkan pertanyaan tersendiri bagi peneliti. Namun dalam hal perambahan hutan di Kawasan TNKS ini tidak sepenuhnya kesalahan dari masyarakat karena masyarakat yang berada di sekitar kawasan taman nasional memiliki areal yang sempit dan terbatas sementara pertumbuhan penduduk semakin meningkat sehingga masyarakat membutuhkan lahan untuk pemenuhan kebutuhan hidup.

Selain pemerintah pusat dapat menyerahkan sebagian urusan di bidang konservasi sumber daya alam hayati dan ekosistemnya kepada pemerintah daerah, pemerintah pusatpun dapat menugaskan kepada Pemerintah Daerah Tingkat I untuk melaksanakan urusan tersebut sebagai tugas pembantuan. Pemerintah sebagai pelestari lingkungan hidup seharusnya meningkatkan pengamanan terhadap wilayah kelolanya dan mencari solusi untuk masyarakat yang menggunakan lahan pertanian dari TNKS sebab perambahan semakin mengkhawatirkan dan mengancam kelestarian TNKS yang sudah ditetapkan sebagai warisan dunia.

Berdasarkan penjelasan di atas yang menjadi tujuan dalam laporan ini adalah untuk mengetahui kewenangan pengawasan pemerintah daerah dalam penanggulangan perambahan hutan di kawasan TNKS dan untuk mengetahui bentuk penanggulangan perambahan hutan oleh BBTNKS di kawasan TNKS wilayah Kabupaten Kerinci. Secara tinci peneliti tertarik untuk mengetahui lebih jauh mengenai pengawasan pemerintah daerah dalam - 
pengelolaan hutan di kawasan TNKS.

Dalam hal ini yang oerlu diperhatikana adalah mengenai pengawasan yang dilakukan oleh pihak dari BBTNKS yang mana pengawasan adalah salah satu fungsi manajemen yaitu "proses kegiatan untuk mengetahui apa yang telah dikerjakan, yang berkaitan dengan evaluasi prestasi kerja, jika perlu melakukan tindakan perbaikan atau tindak lanjut berdasarkan standar atau tolok ukur yang ditetapkan sebelumnya, agar supaya prestasi kerja tercapai sesuai dengan rencana. Fungsi-fungsi fundamental manajemen tersebut juga merupakan sistem." Pengawasan dalam bidang kehutanan diatur dalam Pasal 59 Undang-Undang Republik Indonesia Nomor 41 Tahun 1999, yang menyatakan bahwa pengawasan dimaksudkan untuk mencermati, menelusuri dan menilai pelaksanaan pengurusan hutan, sehingga tujuannya dapat tercapai secara maksimal dan sekaligus merupakan umpan balik bagi perbaikan dan/atau penyempurnaan pengurusan hutan lebih lanjut.

Pengelolaan dan pengurusan hutan merupakan kewenangan pemerintah pusat, namun demikian kewenangan ini dapat diserahkan ke pemerintah daerah, oleh karena itu pemerintah berkewajiban melakukan pengawasan, hal ini sebagaimana yang diatur dalam Pasal 61 yang menyatakan bahwa pemerintah berkewajiban melakukan pengawasan terhadap pengurusan hutan yang diselenggarakan oleh pemerintah daerah. Pengawasanpun dibagi menjadi tiga bagian, yaitu pengawasan umum, pengawasan preventif dan pengawasan represif.

Pada penelitian ini pengawasan yang dilakukan oleh BBTNKS adalah pengawasan represif yang mana pengawasan yang dilaksanakan adalah setelah adanya keputusan/ketentuan itu dilaksanakan. Wujudnya adalah berupa tindakan membandingkan apakah pekerjaan yang sedang/telah dilaksanakan menurut kenyataan telah sesuai dengan ketentuan-ketentuan atau prosedurprosedur yang berlaku/ditetapkan

\section{Tinjauan Pustaka}

Undang-Undang Republik Indonesia Nomor 23 Tahun 2014 menjelaskan bahwa pemerintah daerah memegang peranan sebagai penyelenggara urusan pemerintahan di daerah dan pelaksana tugas pembantuan yakni penugasan dari pemerintah pusat kepada daerah otonom untuk melaksanakan sebagian urusan pemerintahan yang menjadi kewenangan pemerintah pusat atau dari pemerintah daerah provinsi kepada daerah kabupaten/kota untuk melaksanakan sebagian urusan pemerintahan yang menjadi kewenangan daerah provinsi. Sebagaimana yang diatur dalam Pasal 34 Undang-Undang Republik Indonesia Nomor 5 Tahun 1990 dijelaskan bahwa pengelolaan taman nasional, taman hutan raya dan taman wisata alam dilaksanakan oleh pemerintah. Pada Pasal 38 dijelaskan lagi bahwa dalam rangka pelaksanaan konservasi sumberdaya alam hayati dan ekosistemnya, pemerintah dapat menyerahkan sebagian urusan di bidang tersebut kepada pemerintah daerah. Selain pemerintah pusat dapat menyerahkan sebagian urusan di bidang konservasi sumber daya alam hayati dan ekosistemnya kepada pemerintah daerah, juga pemerintah pusat dapat menugaskan kepada pemerintah daerah tingkat I untuk melaksanakan urusan tersebut sebagai tugas pembantuan.

8 Uliana Ria Sembiring, Sistem Pengawasan Pemerintah Daerah, Jurnal IImiah Korpri Kopertis Wilayah IV, Vol 1 No 1, Mei 2016, hlm.143. 
Dalam hal ini, kewenangan pemerintah daerah dalam pelestarian kawasan TNKS hanya dalam bentuk pengawasan.

Dalam ha ini Kabupaten Kerinci termasuk dalam wilayah yang meliputi daerah dataran tinggi dan topografi berbukit sampai dengan bergunung dengan luas wilayah pembangunan 63.833 ha mencakup seluruh Kabupaten Kerinci. Karakter wilayah bergelombang dan berbukit-bukit membentuk enclave yang sangat luas dan sebagian ditutupi hutan lebat yang alami. "Sebagian besar wilayah Kabupaten Kerinci terletak di ketinggian di atas $1000 \mathrm{mdpl}$. Daerah berketinggian antara 500$1000 \mathrm{mdpl}$ seluas $72.246 \mathrm{Ha}$. Sedangkan yang berada di bawah $500 \mathrm{mdpl}$ hanya $6.636 \mathrm{Ha}$ terdapat di Kecamatan Gunung Raya dan Kabupaten Merangin." 9

TNKS merupakan kawasan konservasi yang ditetapkan dengan Keputusan Menteri Kehutanan dan Perkebunan No.901/Kpts-II/1999 seluas $\pm 1.375 .349,867$ ha dan pada tahun 2004 Menteri Kehutanan menetapkan perubahan fungsi kawasan hutan Sipurak Hook seluas \pm 14.160 ha menjadi bagian dari kawasan TNKS dengan surat Keputusan Nomor.420/Menhut-II/2004, sehingga luas kawasan TNKS menjadi $\pm 1.389 .509,867$ ha. Berdasarkan Peraturan Menteri Lingkungan Hidup dan Kehutanan Nomor P.07/Menlhk/Setjen/OTL.0/1/2016 tanggal 10 Februari 2016 tentang Organisasi dan Tata Kerja Unit Pelaksana Teknis Taman Nasional, BBTNKS bertugas melakukan penyelenggaraan konservasi sumber daya alam hayati dan ekosistemnya dan pengelolaan kawasan taman nasional berdasarkan peraturan perundang-undangan.

\section{Metode Penelitian}

Suatu penelitian hukum erat kaitanya terhadap konsep hukum yang digunakan bahwa menurut Soetondyo Wigyosoebroto terhadap lima konsep hukum, konsep-konsep hukum tersebut sebagai berikut:

1. Hukum adalah asas kebenaran dan keadilan yang berlaku kodrati dan berlaku universel;

2. Hukum adalah norma-norma positif di dalam sistem perundang-undangan;

3. Hukum adalah apa yang diputuskan oleh hakim (in concreto) dan tersistemasisasi sebagai judge made law;

4. Hukum adalah pola-pola perilaku sosial yang terlembaga eksis sebagai variabel sosial yang empirik; dan

5. Hukum adalah manifestasi makna-makna simbolik para perilaku sosial sebagai tampak dalam interaksi antar mereka. ${ }^{10}$

Pada konsep hukum pertama, kedua dan ketiga sering disebut dengan konsep hukum doktrinal (normatif), konsep hukum ini merupakan suatu norma, baik yang diindentikan dengan keadilan yang harus diterapkan (ius constituedum) atau norma yang dibentuk dalam suatu perintah atau undang-undang (ius constituetum) agar terjamin kepastian hukumnya. Selanjutnya ada pula norma-norma yang terdapat dalam putusan-putusan yang merupakan produk hakim (judgements), sehingga penelitianpenelitian yang berdasarkan norma-norma hukum tersebut sebagai penelitian doktrinal.

Kemudian pada konsep keempat dan kelima adalah konsep hukum normologi. Menurut Burham Ashofa, "hukum dalam konsep ini merupa-

9 Badan Pusat Statistik Kabupaten Kerinci, Kabupaten Kerinci Dalam Angka 2017, hlm. 6.

10 Setiono, Pemahaman Terhadap Metodologi Penelitian Hukum, Program Studi Ilmu Hukum Pasca Sarjana Universitas Sebelas Maret, Surakarta, 2010, hlm. 20. 
kan bukan sebagai rules akan tetapi sebagai regulaties dalam kehidupan sehari-hari atau pengalaman."11 Sehingga hukum disini sebagai tingkah laku atau aksi-aksi interaksi. Adapun demikian maka penelitian hukum disini disebut sebagai non doktrinal (empiris). Penelitian ini termasuk kedalam penelitian non doctrinal.

\section{Pembahasan}

Sebagai mana yang telah peneliti bahas di atas bahwa terdapat dua pembahasan yang akan di bahas, yaitu mengenai kewenangan pengawasan pemerintah daerah dalam penanggulangan perambahan hutan di kawasan TNKS dan bentuk penanggulangan perambahan hutan oleh BBTNKS di kawasan TNKS wilayah Kabupaten Kerinci. Pertama dalam Undang-Undang Republik Indonesia Nomor 23 Tahun 2014 mendefinisikan bahwa Pemerintah Daerah adalah kepala daerah sebagai unsur penyelenggara Pemerintahan Daerah yang memimpin pelaksanaan urusan pemerintahan yang menjadi kewenangan daerah otonom. Di dalam Pemerintahan Daerah terdapat urusan pemerintahan konkuren yang mana terdiri atas urusan pemerintahan wajib dan urusan pemerintahan pilihan. Dalam hal pengelolaan hutan termasuk urusan pilihan Pemerintah Daerah. Urusan konkuren yang menjadi kewenangan Pemerintah Pusat sebagaimana dijelaskan pada pasal 19 diselenggarakan dengan cara menugasi daerah berdasarkan asas tugas pembantuan.

Berkaitan dengan penyelenggaraan pemerintahan daerah di bidang kehutanan setiap daerah memiliki sebuah badan yang bernama Dinas Kehutanan sebagai unsur pelaksana yang bertugas untuk mengelola hutan dan menjaga kelestarian hutan. Berdasarkan Pasal 21 Undang-Undang Republik Indonesia Nomor 41 Tahun 1999 meliputi kegiatan, tata hutan dan penyusunan rencana pengelolaan hutan, pemanfaatan hutan dan penggunaan kawasan hutan, rehabilitasi dan reklamasi hutan dan perlindungan hutan dan konservasi alam. Sedangkan kegiatan perlindungan terhadap sumberdaya alam hayati dan ekosistemnya yang berada dalam kawasan hutan dilakukan secara terpadu melalui beberapa kegiatan. Hal ini sebagaimana diatur dalam Pasal 5 yang dilakukan melalui kegiatan perlindungan sistem penyangga kehidupan, pengawetan keanekaragaman jenis tumbuhan dan satwa beserta ekositem dan pemanfaatan secara lestari sumber daya alam hayati dan ekosistemnya.

Urusan pemerintahan dibidang kehutanan yang berkaitan dengan pengelolaan taman hutan raya menjadi kewenangan pemerintah daerah, sedangkan pengelolaan taman nasional tidak ada kewenangan pemerintah daerah seperti yang dikatakan bapak Iman Purwanto Kepala seksi Pengendalian kerusakan dan pengamanan hutan Dinas Kehutanan Provinsi Jambi. Beliau mengatakan bahwa, "dalam hal pengelolaan kawasan TNKS itu vertikal yaitu langsung ke pemerintah pusat dan memiliki balai tersendiri yaitu Balai Besar TNKS yang untuk wilayah provinsi jambi ada di Kabupaten Kerinci sedangkan kami Pemerintah Daerah hanya sebatas Fungsi Pengawasan saja karena TNKS berada di daerah Provinsi Jambi. ${ }^{12}$

Terkait pengawasan yang sudah dilakukan lebih lanjut bapak Iman Purwanto menuturkan bahwa, "pengawasan yang kami lakukan dalam -

11 Burhan Ashofa, Metode Penelitian Hukum, Rineka Cipta, Jakarta, 2007, hlm. 10.

12 Wawancara Dengan Bapak Iman Purwanto Kepala Seksi Pengendalian Kerusakan Dan Pengamanan Hutan Dinas Kehutanan Provinsi Jambi Pada Tanggal 9 Juli 2018. 
bentuk adanya koordinasi dengan pihak Balai Besar TNKS, dan koordinasi ini berupa Patroli rutin atau gabungan yaitu mengadakan perondaan di kawasan TNKS yang dilaksanakan oleh polisi kehutanan dari dinas kehutanan Provinsi jambi dan polisi kehutanan dari Balai Besar TNKS di Kabupaten Kerinci yang bertujuan untuk pengamanan hutan dan sosialisasi ke masyarakat akan kegunaan kawasan TNKS."13 Dalam melakukan pengawasan ini, pemerintah daerah mengakui belum efektif, seperti yang dikatakan oleh bapak Adetiawarman seksi perlindungan hutan KSDAE dan pemberdayaan masyarakat Dinas Kehutanan Provinsi Jambi UPTD KPHP Kabupaten Kerinci, beliau mengatakan, "kalau untuk pengawasan memang belum efektif karena kami keterbatasan sumber daya manusia dan anggaran, personil polisi kehutanan kami kurang dan anggaran kami juga belum mencukupi, sehingga kami kesulitan dalam melakukan pengawasan ini." 14

Berdasarkan hasil penelitian yang dilakukan oleh peneliti, meskipun TNKS merupakan kewenangan pemerintah pusat namun pemerintah daerah harus ikut serta dalam menjaga kawasan TNKS ini karena melihat kawasan TNKS yang begitu luas yang tidak memungkinkan untuk dijaga oleh pihak BBTNKS saja dan harus ada katerlibatan dari pemerintah daerah agar pengawasan dan penanggulangan perambahan yang dilakukan efektif. Dalam pengawasan kawasan TNKS pemerintah mendapatkan hambatan yaitu kurangnya personil polisi kehutanan dan minimnya anggaran. Untuk penyelesaian masalah tersebut pemerintah seharusnya melakukan penambahan personil polhut dan membentuk masyarakat mitra polhut supaya pengawasan bisa lebih optimal.

Pemerintah daerah dalam hal melakukan pengawasan hanya dalam bentuk patroli dan sosialisasi saja dan belum memberikan solusi atau perhatian khusus untuk masyarakat yang merambah di kawasan TNKS di Kabupaten Kerinci. Sebagai contohnya masyarakat yang melakukan perambahan membutuhkan lahan untuk pertanian mereka, namun belum ada lahan yang disediakan oleh pemerintah daerah selain kawasan TNKS. Pemerintah daerah tidak bisa sepenuhnya disalahkan karena pemerintah daerah mempunyai hambatan dalam melakukan aktivitas pengawasan misalkan saat pemerintah daerah mengadakan sosialisasi, masyarakat banyak yang tidak paham dan tidak memperdulikan tentang manfaat pelestarian kawasan hutan TNKS karena pada umumnya masyarakat yang hidup kawasan TNKS mayoritas berpendidikan rendah dan sector ekonominya bergantung pada kawasan tersebut yaitu bidang pertanian.

Seperti yang dikatakan Bapak Iman Purwanto mengatakan bahwa "TNKS sepenuhnya kewenangan Balai Besar TNKS dan lahan juga seharusnya dari pihak TNKS yang menyediakan, dari kami pemerintah daerah sudah melakukan berbagai upaya salah satunya penyelesaian konflik tenurial kawasan TNKS yakni kami sudah menyurati ke pemerintah pusat untuk menindaklanjuti dari aktivitas perambahan dikawasan TNKS ini, karena perambahan yang terjadi sudah skala nasional. ${ }^{15}$

Berdasarkan hasil wawancara tersebut, peneliti berkesimpulan bahwa selama ini belum ada

13 Wawancara Dengan Bapak Iman Purwanto Kepala Seksi Pengendalian Kerusakan Dan Pengamanan Hutan Dinas Kehutanan Provinsi Jambi Pada Tanggal 9 Juli 2018.

14 Wawancara Dengan Bapak Adetiawarman Seksi Perlindungan Hutan KSDAE Dan Pemberdayaan Masyarakat Dinas Kehutanan Provinsi Jambi UPTD KPHP Kabupaten Kerinci Pada Tanggal 10 Juli 2018.

15 Wawancara Dengan Bapak Iman Purwanto Kepala Seksi Pengendalian Kerusakan Dan Pengamanan Hutan Dinas Kehutanan Provinsi Jambi Pada Tanggal 10 Juli 2018. 
alternatif yang efektif yang dilakukan oleh pemerintah daerah, yakni dalam hal ini pemerintah daerah belum memberikan lahan yang lain untuk masyarakat yang melakukan perambahan yang membutuhkan lahan untuk tempat pertanian. Kawasan TNKS juga memberikan keuntungan tersendiri bagi daerah yakni seperti yang dikatakan bapak Iman Purwanto Kepala seksi Pengendalian kerusakan dan pengamanan hutan Dinas Kehutanan Provinsi Jambi salah satu keuntungan taman nasional adalah untuk destinasi wisata dan penelitian.

Taman nasional sangat bermanfaat bagi daerah, maka dalam hal ini pemerintah daerah seharusnya menjaga taman nasional dengan baik dari perusakan hutan dan jika kelestarian TNKS sudah terkikis maka akan menimbulkan efek negatif tersendiri bagi daerah terutama masyarakat yang bermukim di sekitar kawasan TNKS. Berkaitan dengan hal mengawasi penanggulangan perambahan pemerintah daerah juga menghadapi kesulitan seperti yang dituturkan Iman Purwanto bahwa "ada penyebab kami untuk sulit mengawasi penanggulangan perambahan hutan khususnya di kawasan TNKS selain terbatasnya kewenangan juga disebabkan oleh adanya konflik sosial dan kepentingan politik.selain itu juga faktor dari masyarakatnya sendiri yang sudah menganggap kawasan TNKS turun temurun dari zaman dahulu." Jika sosialisasi yang diadakan optimal, dan kebutuhan masyarakat terpenuhi maka masyarakat tidak akan merambah dikawasan TNKS lagi. Karena sekarang ini masyarakat merasa kurang diperhatikan oleh pemerintah daerah, sehingga mereka memanfaatkan apa yang ada.
Selain hal-hal tersebut, dari pemerintah Kabupaten Kerinci sendiri sudah berupaya untuk menjaga kawasan TNKS yakni seperti yang dikatakan oleh Adetiawarman, bahwa "pemerintah Kabupaten Kerinci sendiri sudah berusaha dalam menjaga kawasan TNKS yang mana pada tahun 2013 lalu, Bupati Kerinci periode yang dulu yaitu H.Murasman melakukan pengukuhan 5 hutan hak adat di Kabupaten Kerinci. Kelima hutan adat ini merupakan kawasan hutan di luar hutan negara yang menjadi penyangga kawasan TNKS. Dengan dikukuhkannya 5 hutan adat, beliau berharap dapat meningkatkan kepedulian masyarakat dalam menjaga hutan. Hutan adat yang dikukuhkan adalah hutan hak adat tigo luhah permenti yang berenam di Desa Pungut Mudik, Hutan hak adat tigo luhah Kemantan di Desa Kemantan, hutan hak adat lubuk titing di Desa Pungut, hutan hak adat bukit gedang di Desa Pendung Hilir dan hutan hak adat bukit sigi di Desa Tanjung Genting. Keberadaan hutan adat ini sangat penting karena menjadi penyangga kawasan TNKS, melalui hutan adat ini diharapkan akan meningkatkan eksistensi kawasan hutan." ${ }^{16}$

Dengan dikukuhkannya hutan hak adat maka pemerintah daerah dalam hal pengawasan dalam penanggulangan perambahan hutan dapat dibantu oleh pengelola hutan adat yang ditunjuk khususnya di Kabupaten Kerinci, karena pengelola hutan adat memiliki kekuatan hukum untuk menjaga hutan adat yang ditetapkan sebagai penyangga kawasan TNKS. Sehingga adanya penyerobotan dan pengerusakan hutan oleh orang luar dapat dihambat oleh pengelola hutan adat dan dapat mencegah pelaku perambah untuk memasuki kawasan TNKS.

16 Wawancara Dengan Bapak Adetiawarman Seksi Perlindungan Hutan KSDAE Dan Pemberdayaan Masyarakat Dinas Kehutanan Provinsi Jambi UPTD KPHP Kabupaten Kerinci Pada Tanggal 5 Februari 2018. 
Jadi dalam hal pengawasan pemerintah daerah melakukan pengawasan represif yaitu bentuk pengawasan yang dilaksanakan setelah keputusan/ketentuan itu dilaksanakan. Wujudnya adalah berupa tindakan membandingkan apakah pekerjaan yang sedang/telah dilaksanakan menurut kenyataan telah sesuai dengan ketentuan-ketentuan atau prosedur-prosedur yang berlaku/ditetapkan.

Kedua, berkaitan dengan bentuk penanggulangan perambahan hutan oleh BBTNKS di kawasan TNKS wilayah Kabupaten Kerinci, yang mana sama-sama kita ketahui bahwa BBTNKS bertugas melakukan penyelenggaraan konservasi sumber daya alam hayati dan ekosistemnya dan pengelolaan kawasan taman nasional berdasarkan peraturan perundang-undangan. Selanjutnya dalam Pasal 11 Undang-Undang Republik Indonesia Nomor 18 tahun 2013 yang dimaksud perbuatan perusakan hutan meliputi kegiatan pembalakan liar dan/atau penggunaan kawasan hutan secara tidak sah yang dilakukan secara terorganisasi. Masyarakat yang bertempat tinggal di dalam dan/atau di sekitar kawasan hutan yang melakukan penebangan kayu di luar kawasan hutan konservasi dan hutan lindung untuk keperluan sendiri dan tidak untuk tujuan komersial harus mendapat izin dari pejabat yang berwenang sesuai dengan ketentuan peraturan perundang-undangan. Kemudian pada Pasal 12 dijelaskan setiap orang dilarang :

a. Melakukan penebangan pohon dalam kawasan hutan yang tidak sesuai dengan izin pemanfaatan hutan

b. Melakukan penebangan pohon dalam kawasan hutan tanpa memiliki izin yang dikeluarkan oleh pejabat yang berwenang c. Melakukan penebangan pohon dalam kawasan hutan secara tidak sah

d. Memuat, membongkar, mengeluarkan, mengangkut, menguasai, dan/atau memiliki hasil penebangan di kawasan hutan tanpa izin

e. Mengangkut, menguasai, atau memiliki hasil hutan kayu yang tidak dilengkapi secara bersama surat keterangan sahnya hasil hutan

f. Membawa alat-alat yang lazim digunakan untuk menebang, memotong, atau membelah pohon di dalam kawasan hutan tanpa izin pejabat yang berwenang.

g. Memanfaatkan hasil hutan kayu yang diduga berasal dari hasil pembalakan liar, dan lain-lain.

Berdasarkan hasil wawancara dengan kepala bagian perencanaan, perlindungan dan pengawasan di Balai Besar TNKS, "dalam hal kewenangan atau pemegang kendali penuh TNKS yaitu tergantung pada lokasinya. Dalam hal pengawasan dan perlindungan kawasan TNKS BBTNKS juga melakukan koordinasi dengan Balai Konservasi Sumber Daya Alam (BKSDA). Koordinasi yang dilakukan dengan BKSDA yakni yang bersifat Eksitu (di luar kawasan) dan yang bersifat Insitu (di dalam kawasan) adalah kewenangan Balai Besar TNKS."17

Dalam hal menjaga kelestarian hutan TNKS atau penanggulangan perambahan hutan, Balai Besar TNKS memiliki tim khusus yaitu personil Polisi Kehutanan (Polhut). Undang-Undang nomor 18 tahun 2013 mendefinisikan Polisi kehutanan adalah pejabat tertentu dalam lingkup instansi kehutanan -

17 Wawancara Dengan Bapak Sidangan Somad, Kepala Bagian Perencanaan, Perlindungan Dan Pengawasan Di Balai Besar TNKS Pada Tanggal 10 Juli 2018. 
pusat dan/atau daerah yang sesuai dengan sifat pekerjaannya menyelenggarakan dan/atau melaksanakan usaha perlindungan hutan yang oleh kuasa Undang-Undang diberikan wewenang kepolisian khusus dibidang kehutanan dan konservasi sumber daya alam hayati dan ekosistemnya yang berada dalam satu kesatuan komando.

Adapun tugas pokok, fungsi, dan wewenang polisi kehutanan:

a. Tugas pokok adalah menyiapkan, melaksanakan, mengembangkan, memantau dan mengevaluasi serta melaporkan kegiatan perlindungan dan pengamanan hutan serta peredaran hasil hutan.

b. Fungsi polisi kehutanan :

1. Mencegah dan mengatasi kerusakan hutan dan hasil hutan yang disebabkan oleh perbuatan manusia dan ternak, kebakaran, hama dan penyakit.

2. Memperhatikan dan menjaga hak-hak negara atas hutan dan hasil hutan dengan mencegah dan memberantas tindak pidana yang bersifat kejahatan maupun pelanggaran.

3. Menjaga dan melindungi kelestarian alam demiterwujudnya kesejahteraan dan kemakmuran rakyat.

4. Memupuk rasa persatuan, kesatuan dan kebersamaan serta kesetiakawanan dalam lingkungan tugasnya maupun lingkungan masyarakat.

5. Memelihara dan meningkatkan peran serta masyarakat dalam upaya memelihara keutuhan dan kelestarian alam.

c. Wewenang polisi kehutanan

1. Mengadakan patroli/perondaan di dalam kawasan hutan atau wilayah hukumnya.

2. Memeriksa surat-surat atau dokumen yang berkaitan dengan pengangkutan hasil hutan di dalam kawasan hutan atau wilayah hukumnya.

3. Menerima laporan tentang telah terjadinya tindak pidana yang menyangkut hutan, kawasan hutan dan hasil hutan.

4. Mencari keterangan dan barang bukti terjadinya tindak pidana yang menyangkut hutan, kawasan hutan dan hasil hutan.

5. Dalam hal tertangkap tangan, wajib menangkap tersangka untuk diserahkan kepada yang berwenang.

6. Membuat laporan dan menandatangani laporan tentang terjadinya tindak pidana yang menyangkut hutan, kawasan hutan dan hasil hutan.

7. Polisi kehutanan atas perintah pimpinan berwenang untuk melakukan penyelidikan, dalam rangka mencari dan menangkap tersangka (Peraturan Pemerintah Republik Indonesia Nomor 45 tahun 2004 Tentang Perlindungan Hutan). ${ }^{18}$

18 Rahmat Slamet, Studi Tentang Tugas Pokok, Fungsi Dan Wewenang Polisi Kehutanan Dalam Rangka Menjaga Kelestarian Taman Hutan Raya Bukit Suharto, Skripsi, 2015, Hal.10. 
Adapun masalah utama pada kawasan TNKS adalah merupakan perambahan hutan yakni membuka lahan untuk dijadikan ladang tanpa memiliki izin dari pihak yang berwenang. Bentuk perambahan yang banyak terjadi di kawasan TNKS ini berdasarkan hasil wawancara penulis dengan Kepala bagian perencenaan, perlindungan dan pengawasan hutan di BBTNKS yakni dalam bentuk, "aktivitas perambahan di kawasan TNKS tidak seperti di daerah Jambi yang mana dengan cara pembakaran pohon secara keseluruhan melainkan di Kabupaten Kerinci dengan cara Penebangan pohon secara liar, kayu hasil dari penebangan dibiarkan membusuk, kemudian setelah membusuk kayu tersebut dibakar. ${ }^{19}$ Melihat dari realita yang ada, perambahan yang dilakukan peladang selama ini akan mengakibatkan polusi udara dan pencemaran lingkungan. Para peladang tidak peduli terhadap akibat dari aktivitas yang mereka lakukan.

Ada beberapa hal yang sudah dilakukan oleh BBTNKS dalam hal penanggulangan perambahan, yaitu:

\section{a. Patroli}

Yaitu perondaan dalam kawasan hutan untuk pengamanan hutan dari perusakan hutan. Adapun bentuk-bentuk patroli yang sudah dilakukan adalah :

1. Patroli rutin polhut mobile dalam rangka pengamanan kawasan hutan, dilaksanakan minimal 1 kali dalam 1 bulan di masing-masing resort;

2. Patroli bersama masyarakat mitra polhut, dilaksanakan 1 kali dalam 2 bulan; dan
3. Patroli fungsional dalam rangka pencegahan kebakaran hutan.

b. Sosialisasi

Yaitu melakukan penyuluhan ke masyarakat yang bertujuan untuk memberi tahu masyarakat akan keberadaan dan fungsi kawasan TNKS. Sosialisasi ini berupa :

1. Sosialisasi cara pengelolaan TNKS;

2. Sosialisasi tentang Undang-Undang yang mengatur kawasan konservasi; dan

3. Sosialisasi cara penanganan konflik antara manusia dengan satwa.

c. Visit To School

Yaitu pegawai-pegawai BBTNKS berkunjung ke sekolah-sekolah dengan tujuan mensosialisasikan kawasan TNKS.

d. School To Visit, yaitu kegiatan siswa/l sekolah yang berada di Kabupaten Kerinci dan Kota Sungai Penuh.

Seharusnya BBTNKS mampu mengoptimalkan sosialisasi kepada para perambah dengan harapan setelah melakukan sosialisasi para perambah tidak akan melakukan perambahan hutan lagi, karena di dalam kawasan TNKS terdapat banyak spesies hewan dan tanaman langka yang dilindungi yang akan terancam keberadaannya karena aktivitas perambahan yang dilakukan oleh para perambah. Melihat hal-hal yang sudah dilakukan oleh pihak BBTNKS, menurut peneliti sendiri belum maksimal karena hanya masih sebatas sosialisasi dan patroli saja sementara perambahan hutan semakin marak terjadi dari tahun ke tahun. Sehingga sampai saat ini masih belum menghasilkan

19 Wawancara Dengan Bapak Sidangan Somad Kepala Bagian Perencanaan, Perlindungan Dan Pengawasan Di Balai Besar TNKS Pada Tanggal 11 Juli 2018. 
kawasan TNKS yang bebas akan perambahan hutan.

Seperti yang dikatakan oleh Bapak Sidangan Somad kepala bagian perencanaan, perlindungan dan pengawasan di BBTNKS bahwa, "penyebab utama perambahan sulit untuk dijelaskan, salah satunya yaitu masalah ekonomi dan lahan karena untuk kawasan TNKS wilayah Kabupaten Kerinci sampai saat ini perambahnya adalah dominan masyarakat asli Kerinci itu sendiri belum ada masyarakat pendatang berbeda halnya dengan kawasan TNKS di daerah Bangko yang mana pelaku perambah sudah banyak dari masyarakat pendatang. Untuk wilayah Kabupaten Kerinci kawasan TNKS yang banyak dirambah ada di daerah Kayu Aro dibandingkan dengan daerah-daerah lainnya di Kabupaten Kerinci seperti di Renah Pemetik dan Gunung Raya masih tergolong sedikit. ${ }^{20}$

Berdasarkan hasil penelitian di lapangan, menurut peneliti jika perambah dominan berasal dari Kabupaten Kerinci itu sendiri maka perambahan masih bisa diatasi, pihak BBTNKS seharusnya mengetahui apa sebenarnya kebutuhan masyarakat agar tidak melakukan perambahan di kawasan hutan TNKS lagi. Berkaitan dengan penanggulangan perambahan hutan, terdapat beberapa kesulitan dari pihak BBTNKS, yaitu:

a. Kurangnya kesadaran masyarakat akan fungsi kawasan TNKS;

b. Luasnya wilayah TNKS yang menyebabkan sulit untuk dijaga; dan

c. Petugas yang kurang atau sumber daya manusia yang belum optimal, Yang mana jumlah polisi kehutanan di Kabupaten Kerinci hanya berjumlah 78 orang.
Berdasarkan realita di lapangan penelitian mengambil kesimpulan bahwa Kabupaten Kerinci kurang memperhatikan fungsi kawasan TNKS sehingga dipergunakan sesuai keinginannya. Pihak balai TNKS sudah sering melakukan razia atau operasi pencegahan perambahan namun para perambah ataupun peladang tidak mempedulikan bahkan tidak merasa bersalah sama sekali. Ketika diadakan Razia oleh personil Polisi Kehutanan yang bahkan terkadang juga melibatkan pihak aparat keamanan, yaitu TNI dan POLRI, para perambah ini menghindar sementara waktu dari ladang hasil rambahannya dan ketika keadaan sudah aman atau tidak ada Razia lagi mereka kembali ke ladang mereka masing-masing. Selain itu juga melihat kawasan TNKS yang begitu luas sedangkan personil Polisi Kehutanan di wilayah Kabupaten Kerinci hanya berjumlah 78 orang sehingga tidak memungkinkan untuk menjaga wilayah TNKS yang luasnya $\pm 1.990,88 \mathrm{Ha}$. Menurut penulis untuk mengatasi masalah tersebut pemerintah seharusnya melakukan penambahan personil polisi kehutanan dan merekrut warga yang berasal dari desa yang dekat dengan kawasan TNKS untuk menjadi masyarakat mitra polhut dengan harapan supaya pengawasan dapat dioptimalkan. Menurut realita yang ada walaupun personil sudah menyebar ke setiap tempat namun tidak memungkinkan untuk kawasan TNKS terjaga secara keseluruhan, ditambah lagi akses untuk ke lokasi yang sulit dijangkau karena di kawasan TNKS tidak diperbolehkan untuk pembuatan infrastruktur jalan.

Dalam hal ini seharusnya pihak Balai Besar TNKS mencari alternatif lain selai patroli yang bisa membant dalam pencegahan persuahakn hutan di -

$20 \quad$ Wawancara Dengan Bapak Sidangan Somad, Kepala Bagian Perencanaan, Perlindungan Dan Pengawasan Di Balai Besar TNKS Pada Tanggal 11 Juli 2018. 
kawasan TNKS ini.

Berdasarkan data yang peneliti dapatkan dari Bapak Hadinata staf data, evaluasi, pelaporan dan kehumasan bahwa:

Ada beberapa program dari pemerintah pusat untuk masyarakat yang bermukim di sekitar kawasan TNKS yakni kegiatan peningkatan usaha ekonomi masyarakat sekitar kawasan TNKS yaitu pada tahun 2013 di Desa Jernih Jaya Kecamatan Gunung Tujuh Kabupaten Kerinci diberikan Perahu tradisional 6 unit, pelampung 36 buah, dermaga 1 unit dengan nilai bantuan Rp. 36.500.000,- pada tahun 2014 di Desa Pematang Lingkung Kecamatan Batang Merangin Kabupaten Kerinci diberikan Ternak ayam kampung dengan nilai bantuan $\mathrm{Rp}$. 40.000.000,- dan pada tahun 2015 di Desa Kersik Tuo Kecamatan Kayu Aro Kabupaten Kerinci diberikan peralatan mendaki dan rescue dengan nilai bantuan Rp. 40.000.000,- Desa Majunto Lempur Kecamatan Gunung Raya Kabupaten Kerinci diberikan peralatan mendaki dengan nilai bantuan Rp. 40.000.000,- dan Desa Sungai Jernih Kecamatan Gunung Tujuh Kabupaten Kerinci diberikan Peralatan outdoor, Bibit jahe $672 \mathrm{Kg}$, pupuk dan peralatan, Bibit jahe $621 \mathrm{Kg}$, pupuk dan peralatan dengan nilai bantuan Rp. 39.826.000. ${ }^{21}$

Menurut analisis peneliti berdasarkan hasil di lapangan, bahwa pihak BBTNKS memberikan program belum sesuai dengan kebutuhan masyarakat dan belum bisa menghasilkan peladang yang sadar akan ketidak bolehan melakukan pembukaan ladang di kawasan konservasi ini. Karena yang tim teliti serta amati di lapangan berdasarkan wawancara penulis dengan beberapa narasumber dari pihak peladang bahwa kebutuhan mereka adalah lahan bukan yang lain, karena pada umumnya masyarakat yang berladang berpendidikan rendah dan penghasilan sehari-hari mereka hanya dari hasil pertanian.

Seperti yang diungkapkan oleh masyarakat yang bermukim disekitar kawasan TNKS daerah Kayu Aro yaitu bapak Zainal menuturkan, bahwa "kami yang berladang di daerah Kayu Aro dengan tujuan untuk memenuhi ekonomi keluarga, karena sumber mata pencaharian kami memang bergantung dari hasil pertanian kami. Jika kami tidak berladang di daerah Kayu Aro kami tidak mempunyai lahan lain yang untuk dijadikan tempat berladang. Selain itu di daerah Kayu Aro lahannya subur untuk ditanami tanaman seperti kentang, kol dan cabe. ${ }^{22}$

Hal yang sama juga diungkapkan oleh salah seorang peladang di daerah Renah Pemetik yaitu lbu Riaman, mengungkapkan bahwa "kami berladang di Renah Pemetik karena menurut kami lahan yang ada disana sangat cocok untuk bercocok tanam, sementara mata pencaharian kami memang berasal dari pertanian. Jika tidak dengan bertani bisa jadi kami tidak dapat mencukupi kebutuhan sehari-hari kami, belum lagi tuntutan biaya pendidikan untuk anak kami. Sejauh ini kami hanya memiliki ladang di Renah Pemetik saja, dan kami belum pernah mendapat penawaran lahan lain dari pemerintah. ${ }^{23}$

Berdasarkan hasil wawancara dengan penduduk di sekitar kawasan TNKS dalam hal ini juga bukan sepenuhnya kesalahan dari masyarakat karena masyarakat di sekitar kawasan TNKS hidup di areal yang sempit yang sudah dikelilingi kawasan TNKS sementara pertimbuhan penduduk semakin

21 Wawancara Dengan Bapak Hadinata Staf Data, Evaluasi, Pelaporan Dan Kehumasan Di Balai Besar TNKS Pada Tanggal 11 Juli 2017.

22 Wawancara Dengan Bapak Zainal Penduduk Sekaligus Peladang Di Kawasan Tnks Kabupaten Kerinci Pada Tanggal 13 Juli 2018.

23 Wawancara Dengan Ibu Riaman Peladang Di Kawasan Tnks Kabupaten Kerinci Pada Tanggal 13 Juli 2018. 
meningkat sehingga masyarakat memanfaatkan lahan yang bagi mereka tidak difungsikan karena tuntuntan ekonomi.

Kondisi perambahan di kawasan TNKS wilayah Kabupaten Kerinci ini menurut Bapak Sidangan Somad, bahwa "belum masuk ke zona inti namun umumnya masih di Zona tradisional karena di Zona ini terdapat Desa di dalamnya sejak dulu, pada Zona khusus dan Zona rimba masih tergolong sedikit dan peladang yang banyak masuk ke TNKS yaitu di Zona rehabilitasi, dan Zona ini secara perlahan akan di rehab yaitu tanamannya akan diganti dengan tanaman-tanaman kayu dan tanaman tumpang sari." ${ }^{24}$

\section{Mengenai batasan-batasan TNKS} masyarakat banyak yang belum mengetahui, seperti halnya yang dikatakan Ibu Raslina penduduk dan peladang di sekitar kawasan TNKS Kabupaten Kerinci, beliau menuturkan bahwa "untuk batas-batas kawasan saya benar-benar tidak tahu, yang namanya TNKS saja saya baru mendengar semenjak sering ada razia di tempat kami berladang. Dan juga saya belum pernah mendapat sosialisasi dari pemerintah akan fungsi kawasan TNKS. Saya sudah berladang di daerah itu sejak lama karena sumber ekonomi keluarga adalah dari hasil pertanian kami." 25

Masyarakat yang bermukim di sekitar kawasan TNKS Kabupaten Kerinci masih banyak yang belum mengetahui batasan-batasan dan fungsi TNKS karena belum mendapatkan sosialisasi atau penyuluhan dari pihak Balai Besar TNKS, untuk itu pihak balai besar TNKS dan pemerintah daerah seharusnya berusaha untuk memberikan pengetahuan fungsi kawasan TNKS kepada masyarakat dengan harapan akan menumbuhkan kesadaran masyarakat untuk menjaga kelestarian hutan. Para peladang enggan untuk meninggalkan ladang mereka karena menurut mereka lahan yang mereka tanami sudah mereka miliki sejak lama. Untuk menyelesaikan permasalahan diatas diperlukan juga sosialisasi kepada anak-anak yang tinggal di sekitar kawasan TNKS dengan harapan agar generasi selanjutnya tidak melakukan perambahan hutan. Bapak Zalfinur, mengatakan "jika untuk mengusir para peladang dari kawasan TNKS itu susah, karena mereka sudah mendiami lahan mereka sejak lama dan bagi mereka lahan itu milik mereka. Dan juga tidak memungkinkan untuk mengusir mereka dari lahan mereka, karena bercocok tanam adalah sumber mata pencaharian mereka." 26

Terkait penanggulangan yang sudah berusaha dilakukan oleh pihak Balai Besar TNKS bapak Sidangan Somad lebih lanjut mengatakan, "kami dari pihak BBTNKS sudah berusaha semaksimal mungkin dan seharusnya dalam hal ini pemerintah daerah lebih ikut berpartisipasi seperti contohnya menekankan kepada Desa-desa yang dekat dengan kawasan TNKS untuk menghentikan warga masyarakatnya melakukan perambahan sehingga penanggulangan perambahan dapat berjalan lebih maksimal lagi. ${ }^{27}$

Berikut peneliti sajikan data perambahan hutan di kawasan TNKS 5 (lima) tahun terakhir yaitu dari tahun 2013-2017, yaitu:

24 Wawancara Dengan Bapak Sidangan Somad, Kepala Bagian Perencanaan, Perlindungan Dan Pengawasan Di Balai Besar TNKS Pada Tanggal 14 Juli 2018.

25 Wawancara Dengan Ibu Raslina Penduduk Dan Peladang Di Kawasan Tnks Pada Tanggal 13 Juli 2018.

26 Wawancara Dengan Bapak Zalfinur Kepala Desa Jernih Jaya Pada Tanggal 12 Juli 2018

27 Wawancara Dengan Bapak Sidangan Somad, Kepala Bagian Perencanaan, Perlindungan Dan Pengawasan Di Balai Besar TNKS Pada Tanggal 13 Juli 2018. 
16 Ivan Fauzani Raharja dkk, Kewenangan Balai Besar Taman Nasional.....

\begin{tabular}{ccc}
\hline \multirow{2}{*}{ Tahun } & \multicolumn{2}{c}{ Banyak perambahan (Ha) } \\
& Provinsi Jambi & Kabupaten Kerinci \\
\hline 2013 & 28.255 & 24.700 \\
2014 & 28.255 & 6.720 \\
2015 & 28.255 & Belum ada di dokumen \\
2016 & 28.255 & Belum ada di dokumen \\
2017 & 28.255 & Belum ada di dokumen \\
\hline
\end{tabular}

Sumber : Dokumen Balai Besar Taman Nasional Kerinci Sebelat tahun 2017

Berdasarkan data perambahan yang penulis dapatkan, pihak BBTNKS belum secara rutin melakukan pengevaluasian data-data perambahan, karena masih banyak yang belum tercatat pada dokumen kantor Balai Besar TNKS khususnya perambahan yang di Kabupaten Kerinci sedangkan yang paling banyak terjadi perambahan adalah di Kabupaten Kerinci.

\section{Penutup}

\subsection{Kesimpulan}

1. Dalam melakukan pengawasan terhadap penanggulangan perambahan hutan di kawasan TNKS, pemerintah daerah dalam hal ini Dinas Kehutanan Provinsi Jambi melakukan koordinasi dengan BBTNKS selaku pihak yang berwenang dalam pengelolaan, koordinasi yang dilakukan yakni dalam bentuk Patroli Rutin atau gabungan yaitu perondaan dalam kawasan hutan yang dilaksanakan oleh Polisi Kehutanan Dinas Kehutanan Provinsi Jambi dengan Polisi Kehutanan BBTNKS, Sosialisasi kepada masyarakat akan fungsi kawasan TNKS dengan tujuan agar tidak melakukan perambahan hutan lagi.

2. Dalam melakukan penanggulangan perambahan pihak BBTNKS sudah melakukan Patroli yakni Patroli Polhut Mobile dalam rangka pengamanan kawasan hutan yang dilaksanakan minimal 1 kali dalam 1 bulan di masing-masing resort, patroli bersama masyarakat mitra Polhut yang dilaksanakan 1 kali dalam 2 bulan dan patroli fungsional dalam rangka pencegahan kebakaran hutan. Sosialisasi yakni Sosialisasi cara pengelolaan TNKS, Sosialisasi tentang Undang-Undang yang mengatur kawasan konservasi, dan Sosialisasi cara penanganan konflik antara manusia dengan satwa. Visit to school dan school to Visit yakni berkunjung ke sekolahsekolah untuk memberikan pengetahuan akan fungsi kawasan TNKS, Pengawasan pemerintah daerah dalam penanggulangan perambahan hutan di kawasan TNKS di Kabupaten Kerinci belum terlaksana dengan efektif. 
5.2. Saran

1. Dalam rangka melakukan pengawasan pemerintah daerah hendaknya lebih mengoptimalkan lagi dan lebih memperhatikan lagi akan kebutuhan masyarakat, karena mengingat kawasan TNKS berada di daerah Provinsi Jambi dalam hal ini khususnya di Kabupaten Kerinci.

2. Mengingat hal-hal yang dilakukan BBTNKS hanya berupa sosialisasi dan patroli saja, ada baiknya BBTNKS mengeluarkan alternatif lain agar dapat menanggulangi perambahan hutan di kawasan TNKS.

3. Dalam hal keterbatasan sumber daya manusia yaitu personil polisi kehutanan maka hendaknya Balai Besar TNKS mengajukan permohonan perihal penambahan anggota polisi kehutanan mengingat kawasan TNKS yang dijaga terlalu luas.

\section{DAFTAR PUSTAKA}

\section{Buku}

Ashofa, Burhan. Metode Penelitian Hukum. Jakarta: Rineka Cipta, 2007.

Badan Pusat Statistik Kabupaten Kerinci. Kabupaten Kerinci Dalam Angka 2017.

Setiono. Pemahaman Terhadap Metodologi Penelitian Hukum. Surakarta: Program Studi IImu Hukum Pasca Sarjana Universitas Sebelas Maret, 2010.

Supriadi. Hukum Kehutanan Dan Hukum Perkebunan Di Indonesia. Cet.2. Jakarta: Sinar Grafika, 2011.

Syafiie, Inu Kencana. IImu Pemerintahan, Cetakan 2. Jakarta: Bumi Aksara, 2014.

Yusuf, Abdul Muis \& Mohammad Taufik Makarao. Hukum Kehutanan Di Indonesia. Jakarta: Rineka Cipta, 2011.

\section{Artikel}

Adiprasetyo. "Sikap Masyarakat Lokal Terhadap Konservasi Dan Taman Nasional Sebagai Pendukung Keputusan Dalam Pengelolaan
Taman Nasional Kerinci Seblat (Studi Kasus Di Kabupaten Kerinci Indonesia)." Jurnal Bumi Lestari , 2009: 9.

Ashofa, Burhan. Metode Penelitian Hukum. Jakarta: Rineka Cipta, 2007.

Diantoro, Totok Dwi. "Perambahan Kawasan Hutan Pada Konservasi Taman Nasional." Mimbar Hukum 23, No. 3 (n.d.).

Sembiring, Uliana Ria. "Sistem Pengawasan Pemerintah Daerah." Jurnal IImiah Korpri Kopertis Wilayah IV 1, No. 1 (2016).

Slamet, Rahmat. "Studi Tentang Tugas Pokok, Fungsi Dan Wewenang Polisi Kehutanan Dalam Rangka Menjaga Kelestarian Taman Hutan Raya Bukit Suharto." Skripsi, 2015.

\section{Peraturan Perundang-Undangan}

Undang-Undang Republik Indonesia Nomor 5 Tahun 1990 Tentang Konservasi Sumberdaya Alam Hayati dan Ekosistemnya

Undang-Undang Republik Indonesia Nomor 41 Tahun 1999 Tentang Kehutanan. 
Ivan Fauzani Raharja dkk, Kewenangan Balai Besar Taman Nasional.....

Undang-Undang Republik Indonesia Nomor 23 tahun 2014 Tentang Pemerintahan Daerah.

Peraturan Pemerintah Republik Indonesia Nomor 45 tahun 2004 Tentang Perlindungan Hutan.

\section{Sumber Lain}

Wawancara Dengan Bapak Iman Purwanto Kepala Seksi Pengendalian Kerusakan Dan Pengamanan Hutan Dinas Kehutanan Provinsi Jambi.

Wawancara Dengan Bapak Adetiawarman Seksi Perlindungan Hutan KSDAE Dan Pemberdayaan Masyarakat Dinas Kehutanan Provinsi Jambi UPTD KPHP Kabupaten Kerinci.
Wawancara Dengan Bapak Sidangan Somad, Kepala Bagian Perencanaan, Perlindungan Dan Pengawasan Di BBTNKS.

Wawancara Dengan Bapak Hadinata Staf Data, Evaluasi, Pelaporan Dan Kehumasan Di BBTNKS.

Wawancara Dengan Bapak Zainal Penduduk Sekaligus Peladang Di Kawasan TNKS Kabupaten Kerinci.

Wawancara Dengan Ibu Raslina Penduduk Dan Peladang Di Kawasan TNKS.

Wawancara Dengan Bapak Zalfinur Kepala Desa Jernih Jaya 